\title{
Interlock Recovery During the Drying, Calcination and Vitrification Phase of $\mathrm{Am} / \mathrm{Cm}$ Processing
}

by

T. K. Snyder

Westinghouse Savannah River Company

Savannah River Site

Aiken, South Carolina 29808

D. C. Witt

DOE Contract No. DE-AC09-96SR18500

This paper was prepared in connection with work done under the above contract number with the U.S. Department of Energy. By acceptance of this paper, the publisher and/or recipient acknowledges the U. $S$. Government's right to retain a nonexclusive, royalty-free license in and to any copyright covering this paper, along with the right to reproduce and to authorize others to reproduce all or part of the copyrighted paper. 
Date: $12 / 14 / 99$

\section{TO: W. H. MARTIN, 730-2B}

FROM: L.F. LANDQNYTH

\section{INTERLOCK RECOVERY DURING AM/CM PROCESSING}

The attached document summarizes the results of five CIM5 runs designed to demonstrate power interlock recovery methods during the drying, calcination and vitrification phases of the $\mathrm{Am} / \mathrm{Cm}$ melter cycle. These tests were conducted in $\mathrm{Am} / \mathrm{Cm}$ Pilot Facility located in Building 672-T. Please refer any questions you may have regarding the contents of this document to T. K. Snyder (Ext. 7-7682) or D. C. Witt (Ext. 7-7754)

\section{DISTRIBUTION}

J. T. Dahlstrom, 730-1B

A. W. Bowers, 704-10F

A. P. Giordano, 730-1B

A. P. Fellinger, 730-1B

N. H. Harkey, 730-1B

D. C. Witt, 704-1T

T. K. Snyder, 704-T

STI 703-43A (4) 
WSRC-TR-99-00457, Revision 0

\section{INTERLOCK RECOVERY DURING THE DRYING, CALCINATION AND VITRIFICATION PHASES OF AM/CM PROCESSING (U)}

T. K. SNYDER

D. C. WITT

Westinghouse Savannah River Company

Savannah River Site

Aiken, SC 29808

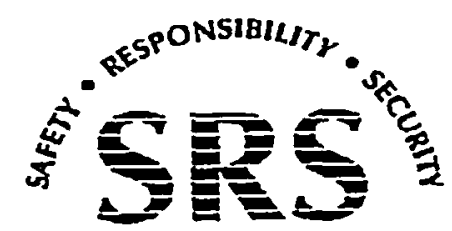

PREPARED FOR THE U.S. DEPARTMENT OF ENERGY UNDER CONTRACT NO. DE-AC09-96SR18500 


\section{DISCLAIMEIR}

This report was prepared as an account of work spoasored by an agency of the United States Government. Neither the United States Government nor any agency thereof, nor any of their employees, makes any warranty, express or implied, or assumes any legal liability or responsibility for the accuracy, completeness, or usefulness of any information, apparatus, product or process disclosed, or represents that its use would not infringe privately owned rights. Reference herein to any specific commercial product, process or service by trade name, trademark, manufacturer, or otherwise does not necessarily constitute or imply its endorsement, recommendation, or favoring by the United States Government or any agency thereof. The views and opinions of authors expressed herein do not necessarily state or reflect those of the United States Government or any agency thereof.

This report has been reproduced directly from the best available copy.

Available for sale to the public, in paper, from: U.S. Department of Commerce, National Technical Information Service, 5285 Port Royal Road, Springfield, VA 22161, phone: (800) 553-6847

fax: (703) 605-6900

email: orders@ntis.fedworld.gov

online ordering: http://www.ntis.gov/ordering.htm

Available electronically at http://www.doe.gov/bridge

Available for a processing fee to U.S. Department of Energy and its contractors, in paper, from: U.S. Department of Energy, Office of Scientific and Technical Information, P.O. Box 62, Oak Ridge, TN 37831-0062, phone: (865) 576-8401

fax: (865) 576-5728

email: reports@adonis.osti.gov 


\section{DISCLAIMER}

\section{Portions of this document may be illegible in electronic image products. Images are produced from the best available original document.}


WSRC-TR-99-0457, Revision 0

ITS Activity No. ITS-99-0100

Keywords: Am/Cm, CIM5

Interlock Recovery

Retention: Permanent

\section{INTERLOCK RECOVERY DURING THE DRYING, CALCINATION AND VITRIFICATION PHASES OF AM/CM PROCESSING (U)}

T. K. SNYDER

D. C. WITT

i

Publication Date: $\quad 12 / 6 / 99$

Westinghouse Savannah River Company

Savannah River Site

Aiken, SC 29808

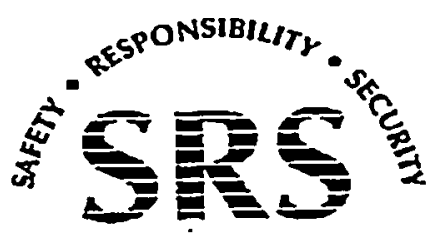

PREPARED FOR THE U.S. DEPARTMENT OF ENERGY UNDER CONTRACT NO. DE-AC09-96SR18500 


\section{APPROVALS}

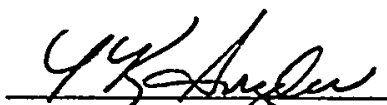

T. K. Snyder, Atthor

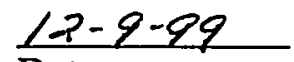

Immobilization Technology Section

Plustif

D. C. Witt, Author

$12 / 9 / 99$

Date

Immobilization Technology Section

mostoreo

T. M. Jones, Technical Reviewer

$12-9-99$

Immobilization Technology Section

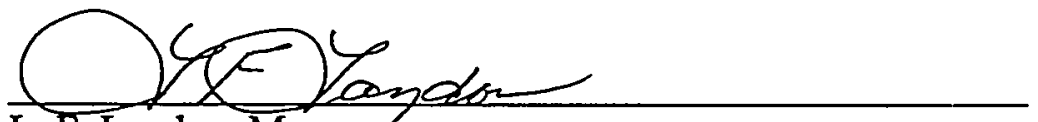

L. F. Landon, Managet

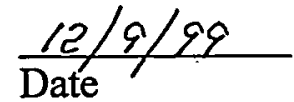

Immobilization Technology Section 


\section{TABLE OF CONTENTS}

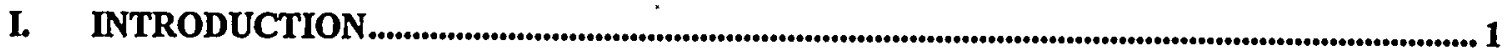

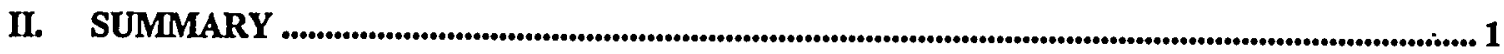

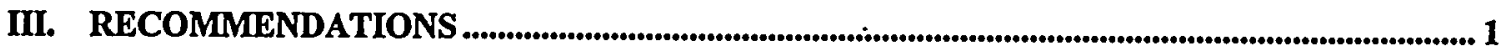

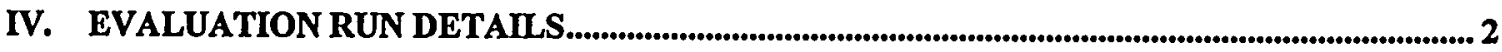

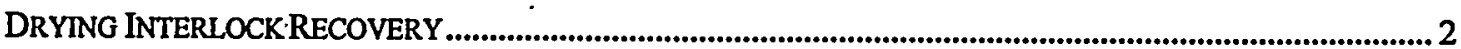

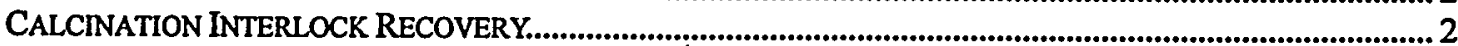

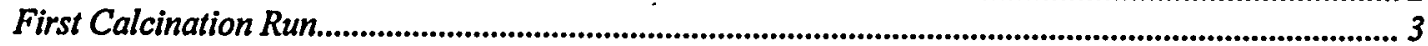

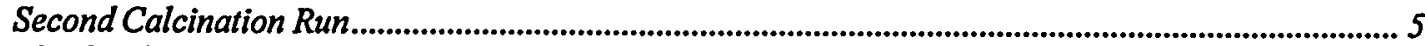

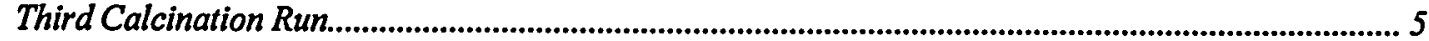

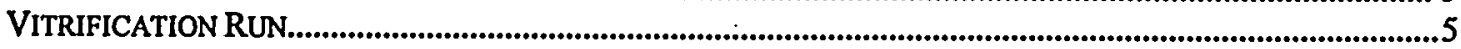

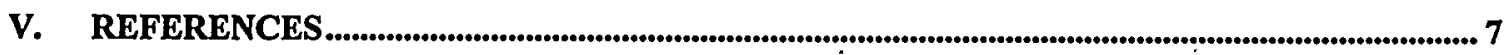

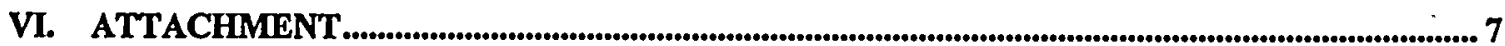

\section{LIST OF FIGURES}

Figure 1. Temperature Traces for Drying Interlock Recovery Run.....................................3

Figure 2. Temperature Traces for CIM5 Standard Run......................................................4.

Figure 3. Temperature Traces for Calcination Recovery Run.................................................4

Figure 4. Cone Wall Temperature ..................................................................................6

Figure 5. Bed Temperatures..................................................................................................6

Figure 6. Temperature Profile for Vitrification Interlock Recovery Run.............................7 
WSRC-TR-99-00457

ITS Activity No. ITS-99-0100

Page 1 of 8

\section{INTRODUCTION}

Five CIM5 runs to demonstrate power interlock recover methods during drying, calcination and vitrification phases began on 11/3/99 and were completed on 11/23/99. These runs were performed to support TTR\#99-NMSS/SE-006, Task 3.03, ITS Activity Number ITS99-0100. The interlocks were triggered at the conditions listed below:

Drying: Interlock occurred after 75-80 minutes of the automated power sequence (run time).

Calcination: Interlock occurred at the 251 minute mark of the automated power sequence (run time).

Vitrification: Interlock occurred at the 350 minute mark of the automated power sequence (run time).

The melter was allowed to cool overnight ( $\sim 17$ hours) to ambient temperature and recovery was then attempted. (Note: During one test a facility power outage resulted in an elapsed period of nearly 91 hours before recovery was initiated.) Due to a bed expansion experienced during the first calcination interlock run, two subsequent calcination interlock runs were completed.

\section{SUMMARY}

No anomalies were encountered during the drying and vitrification interlock recovery runs. However, recovery from an interlock that occurs during calcination produced a bed expansion that had to be manually vented. Although the wall temperatures during recovery match those for a standard run without an interlock, the bed temperature profile is different, suggesting a physical change in the precipitate/cullet bed. This physical change appears to inhibit gas removal from the bed during cerium reduction.

No further investigation into the mitigation of the bed expansion during recovery from a calcination interlock is planned at this time. Further direction will be provided by the Design Authority.

\section{RECOMMENDATIONS}

In consultation with SRS and industry experts, define an R\&D program to develop an understanding why recovery from the calcination phase results in an unacceptable bed expansion. This program should address the following issues: 
WSRC-TR-99-00457

ITS Activity No. ITS-99-0100

Page 2 of 8

- Temperature range in which recoverability is accompanied by an unacceptable bed expansion?

- Length of time the melter can experience a loss of power during the calcination phase without experiencing an unacceptable bed expansion during resumption of the heating cycle?

- Technique(s) for mitigating volume expansion during recovery from an extended interlock.

- Redundancy in design of those systems that can result in a loss of power.

- Increasing the height of the melter to accommodate the bed expansion.

Additional funding must be provided for the above tasks because the current FY00 funding level will not support activities beyond that defined in the current Task Technical Plan.

\section{EVALUATION RUN DETAILS}

Each run was performed using a standard $49 \mathrm{wt} \% \mathrm{Ln}$ loaded glass and was processed utilizing the automated power sequence program of the Factory Link control system. This automated power sequence program begins at Run Time 0 and continues through drying (wall temperatures from startup to $250^{\circ} \mathrm{C}$ ), calcination (wall temperatures from $251^{\circ} \mathrm{C}$ to $1000^{\circ} \mathrm{C}$ ) and vitrification (wall temperatures from $1000^{\circ} \mathrm{C}$ to $1450^{\circ} \mathrm{C}$ ). The thermocouple locations are shown in Attachment 1.

\section{Drying Interlock Recovery}

At Run time $=75$ minutes, all power to the melter was removed by inducing a system interlock. Approximately $1 / 4$ " of free liquid remained above the solids bed after the boiling stopped as a result of the induced power interlock and subsequent melter cooldown. The following day, the automated power sequence program was restarted at Run Time $=0$ and the interlock recovery run completed. There were no anomalies encountered during the interlock recovery run. The temperature traces during the interlock recovery runs are shown in Figure 1. For comparison purposes temperature traces for a standard run producing a 49 wt\% Ln glass are presented in Figure 2.

\section{Calcination Interlock Recovery}

Recovery from an interlock that occurs during calcination produced a bed expansion that had to be manually vented. Although the wall temperatures during recovery match those for a standard run without an interlock, the bed temperature profile is different, suggesting a physical change in the precipitate/cullet bed. This physical change may inhibit gas removal from the bed during cerium reduction. 
WSRC-TR-99-00457

ITS Activity No. ITS-99-0100

Page 3 of 8

\section{First Calcination Run}

At Run Time $=251$ minutes, just after covering the vessel open top with an insulating board, all power to the melter was removed by inducing a system interlock. Sixty seven hours later the automatic power control sequence was to have been restarted at Run Time $=0$ and the calcination interlock recovery run completed. However, electrical service to Building 672-T was lost and not restored until 24 hours later at which time the recovery run was completed. This run produced a bed expansion just prior to reaching Run Time $=350$ where the peak power soak/bubbling phase begins. The top insulating cover was lifted by the bed expansion and the foam surface had to be manually vented. Following 75 minutes of sparging, the glass was poured producing a homogeneous glass product. Temperature traces for the recovery runs are displayed in Figure 3.

Figure 1. Temperature Traces for Drying Interlock Recovery Run

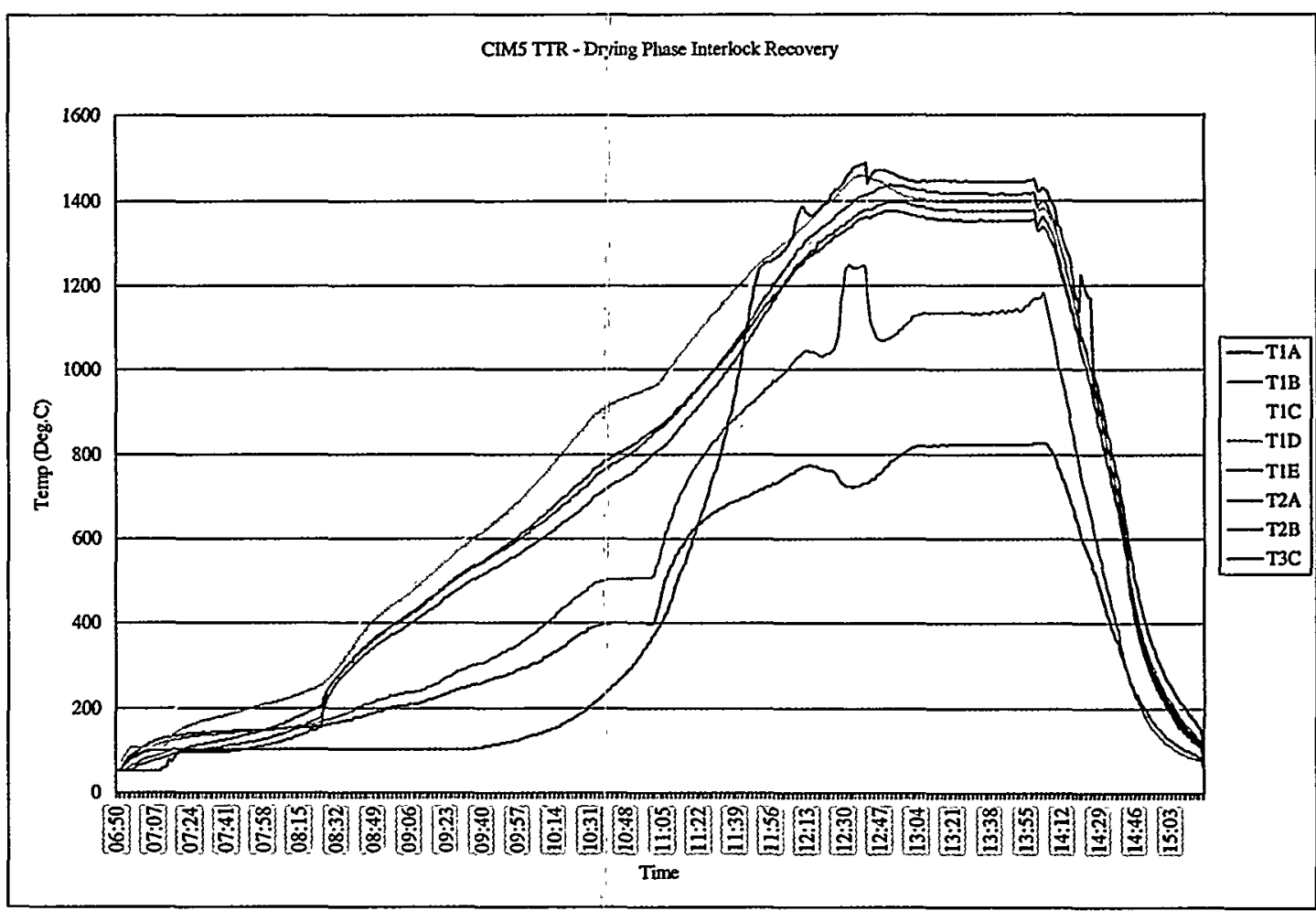


WSRC-TR-99-00457

ITS Activity No. ITS-99-0100

Page 4 of 8

Figure 2. Temperature Traces for CIM5 Standard Run

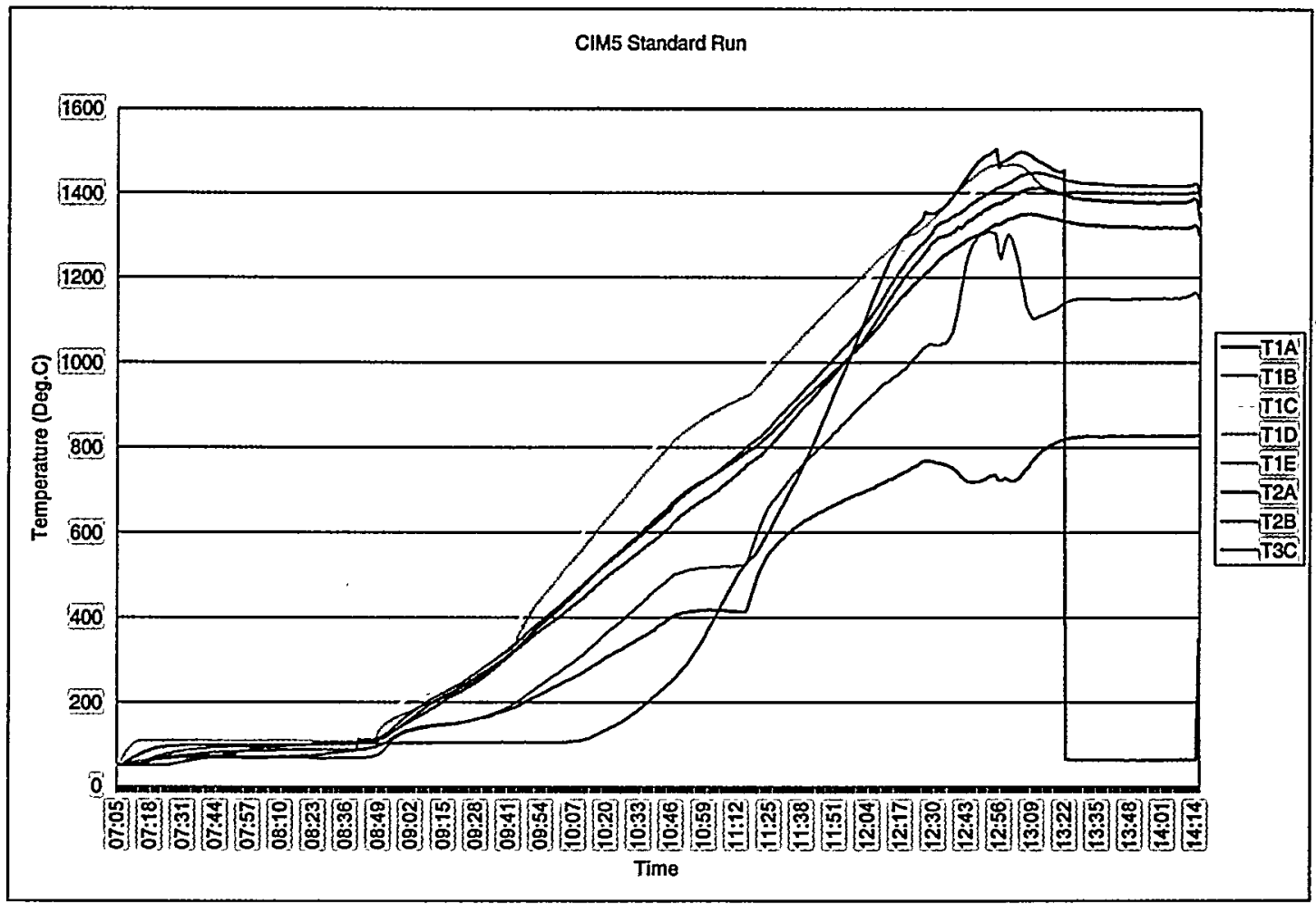

Figure 3. Temperature Traces for Calcination Recovery Run

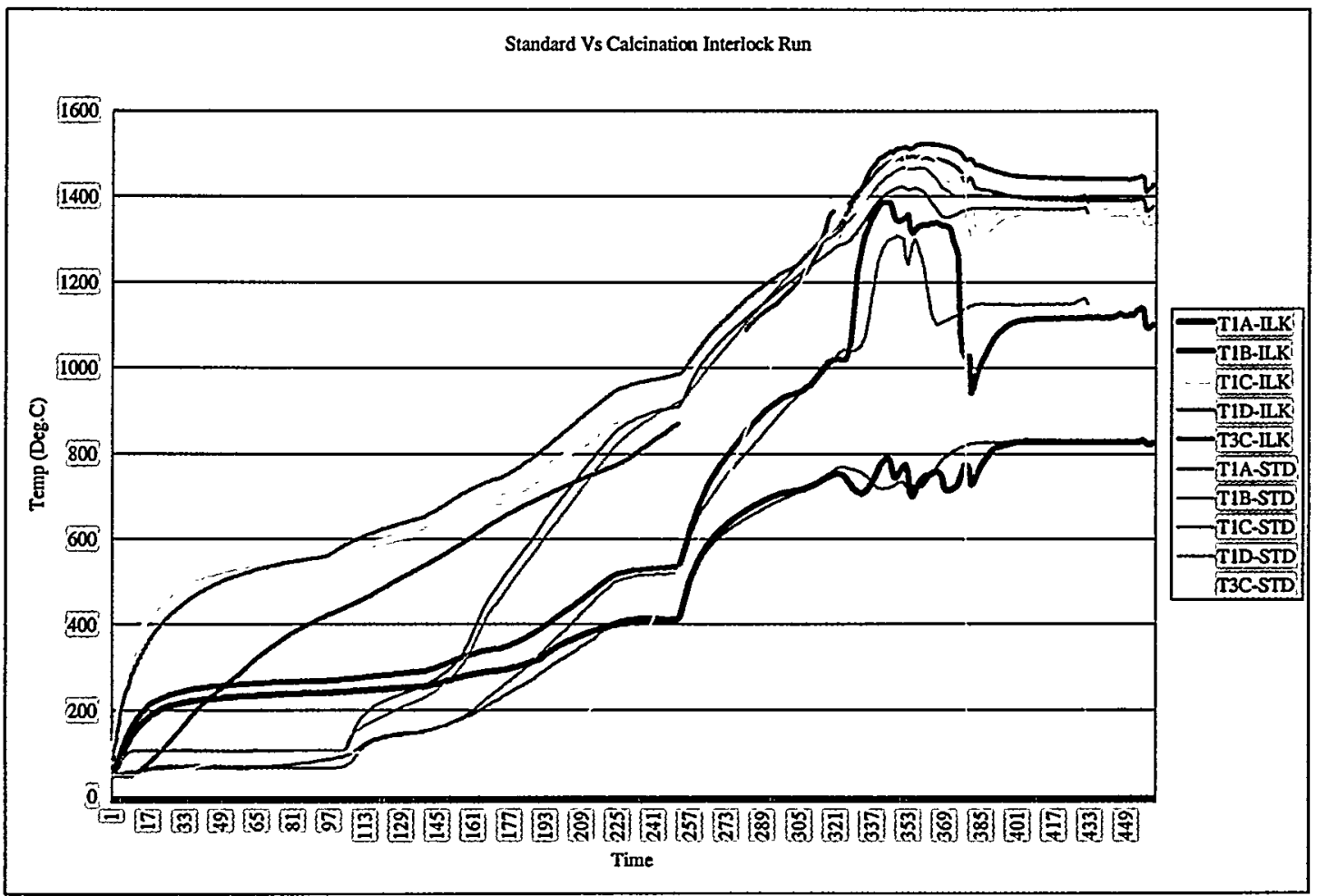


WSRC-TR-99-00457

ITS Activity No. ITS-99-0100

Page 5 of 8

\section{Second Calcination Run}

The primary purpose of this run was to determine if the bed expansion in the first calcination run could be duplicated. At Run Time $=251$ minutes, all power to the melter was again removed by inducing a system interlock. This recovery run was initiated the following day as opposed to the 91 hour hold on the first calcination run and yielded nearly identical results with the bed expansion occurring at the same point and lifting the insulating cover.

\section{Third Calcination Run}

To evaluate a potential method for recovery, a third calcination interlock run was conducted on 11/22 and 11/23. $1700 \mathrm{ml}$ of water was added to the cooled melter prior to starting the recovery run. The purpose was to provide a heat load to the previously dried and partially calcined batch bed which would result in a temperature profile upon reheating that resembled more closely that of the initial heating profile for standard runs. This did not however, mitigate the bed expansion. At Run Time $=335$ of the recovery run, the bed expansion reached the insulating cover board on top of the melter vessel. Three minutes later the foam lifted the cover and was manually vented. A second expansion again lifted the board five minutes later. Cone wall temperature traces and bed temperature traces for each of the calcination recovery runs are compared with a standard run in Figures 4 and 5 , respectively. In Figure 4, T2A-1, T2A-2, and T2A-3 represent the T2A cone wall temperature for the first, second and third calcination recovery runs. In Figure 5 the bed temperatures for these runs are denoted by T3C-1, T3C-2, and T3C-3. At Run Time $=350$, all the foam was incorporated back into the glass pool. Glass pouring was then completed without incident.

\section{Vitrification Run}

At Run Time $=350$, just after installing the glass bubbler at a 1 " elevation from the melter bottom, and initiating argon flow at $1.5 \mathrm{scfh}$ all power to the melter was removed by inducing a system interlock. The following day, the automated power sequence program was restarted at Run Time $=0$ and the interlock recovery run completed. There were no anomalies encountered during the interlock recovery run. The temperature traces for the interlock recovery are shown in Figure 6. 
WSRC-TR-99-00457

ITS Activity No. ITS-99-0100

Page 6 of 8

Figure 4. Cone Wall Temperature

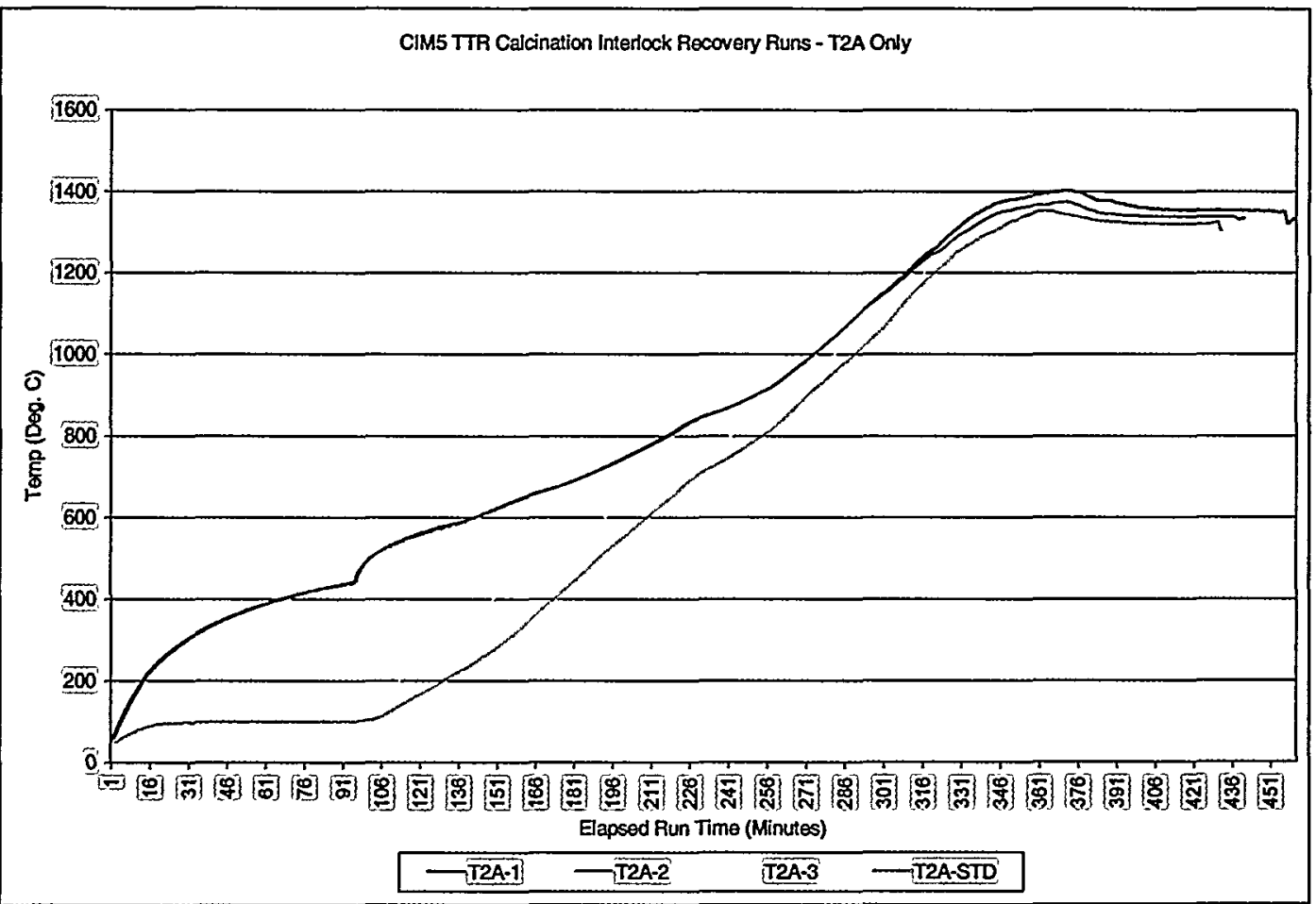

Figure 5. Bed Temperatures

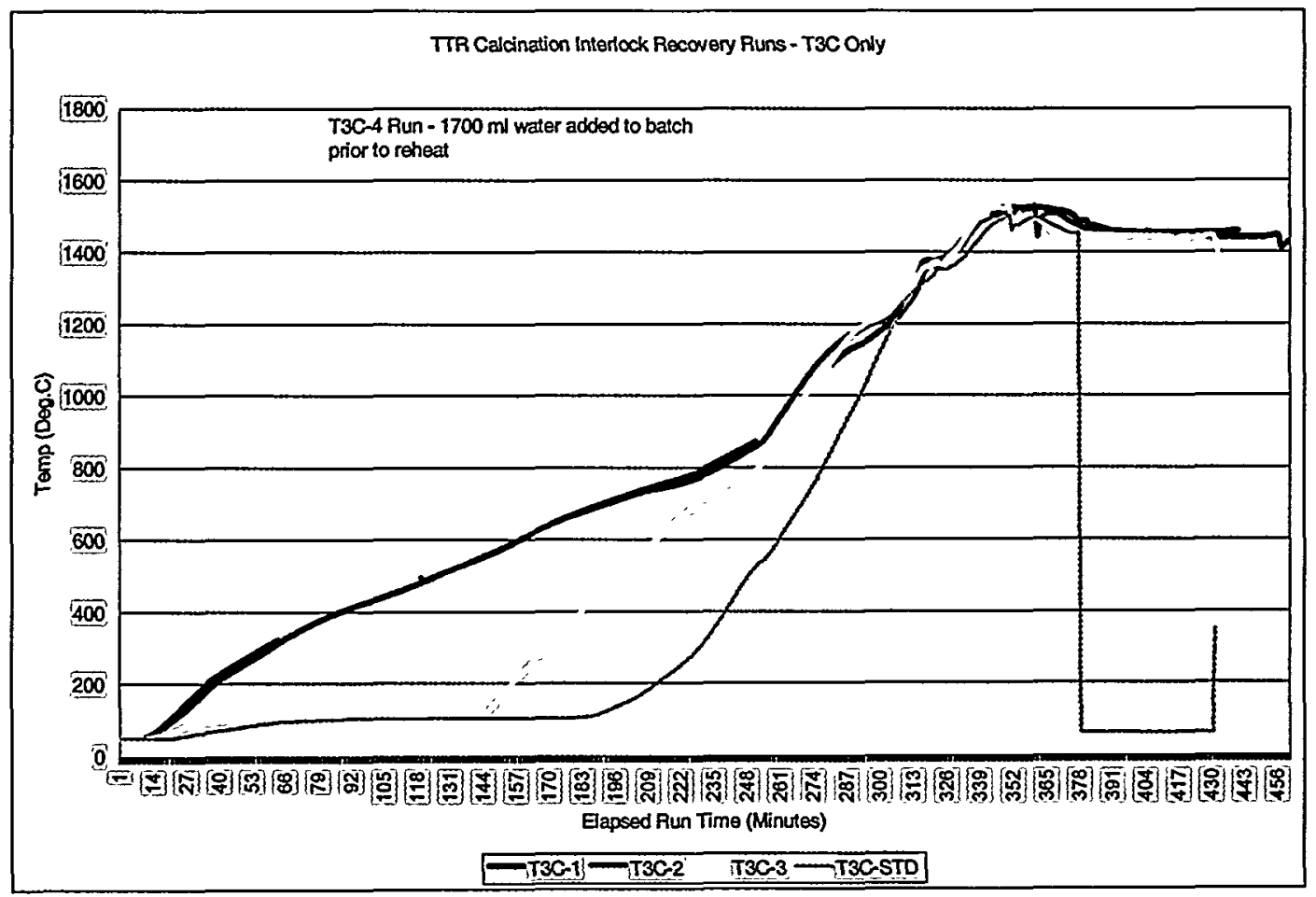


WSRC-TR-99-00457

ITS Activity No. ITS-99-0100

Page 7 of 8

Figure 6. Temperature Profile for Vitrification Interlock Recovery Run

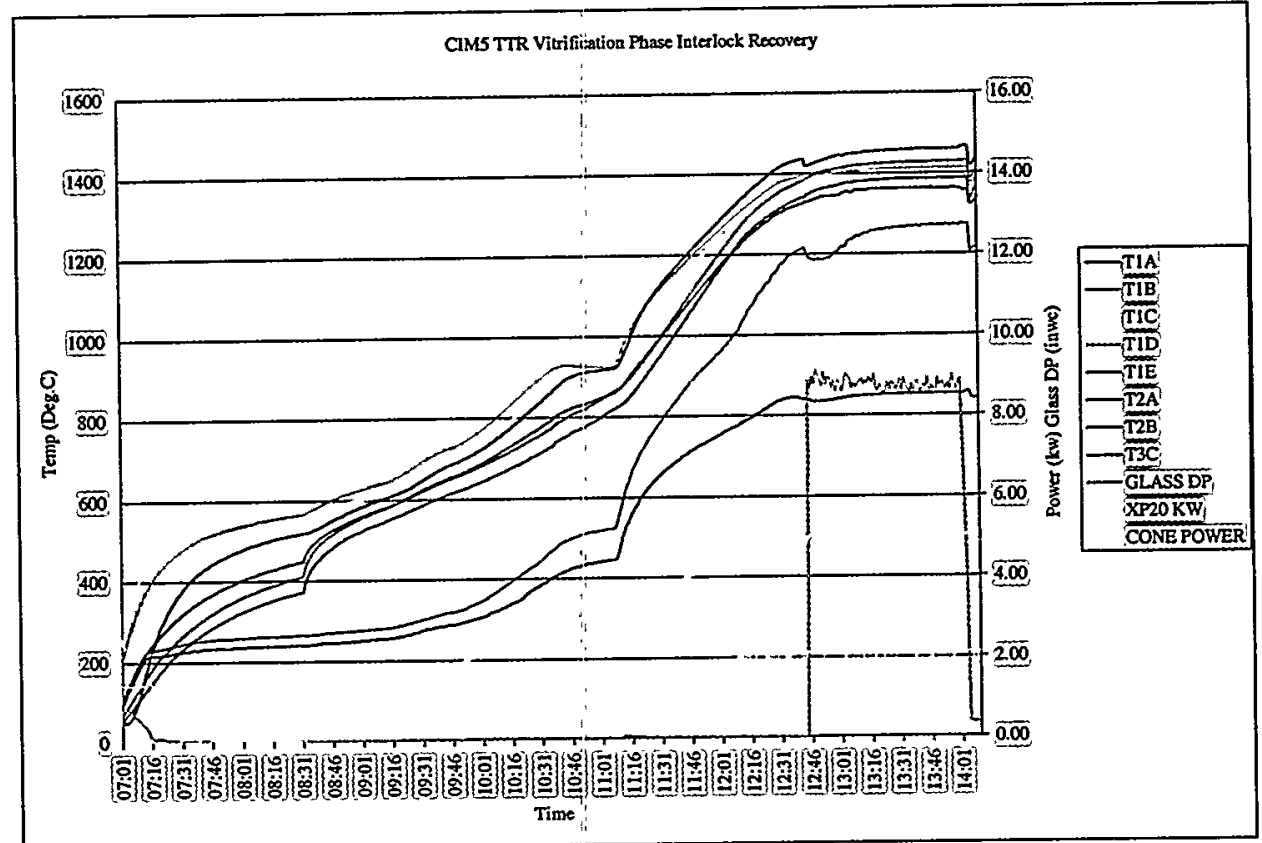

\section{REFERENCES}

1. T. M. Jones and D. C. Witt, CIM5 TTR Task 3.03 - Interlock Recovery During Drying Phase, SRT-AMC-99-0214, November 3, 1999.

2. T. M. Jones and D. C. Witt, CIM5 TTR Task 3.03 - Interlock Recovery During Calcination Phase, SRT-AMC-99-0215, November 3, 1999.

3. T. M. Jones and D. C. Witt, CIM5 TTR Task 3.03 - Interlock Recovery During Vitrification Phase, SRT-AMC-99-0216, November 3, 1999.

4. T. M. Jones and D. C. Witt, CIM5 TTR Task 3.03 - Interlock Recovery During Calcination Phase (Second Run), SRT-AMC-99-0217, November 15, 1999.

5. T. M. Jones and D. C. Witt, CIM5 TTR Task 3.03 - Interlock Recovery During Calcination Phase (Third Run), SRT-AMC-99-0218, November 22, 1999.

6. W. H. Martin, NMS-EFA-99-0054, Additional 5" CIM Operational Studies TTR\# 99-NMSS/SE-006, April 28, 1999.

7. WSRC-NB-99-00173, WSRC Laboratory Notebook, 5" Cylindrical Induction Melter Development.

VI. ATTACHMENT

Attachment 1-CIM5 Thermocouple Placement 
WSRC-TR-99-00457

ITS Activity No. ITS-99-0100

Page 8 of 8

Attachment 1

\section{CIM5 THERMOCOUPLE PLACEMENT}

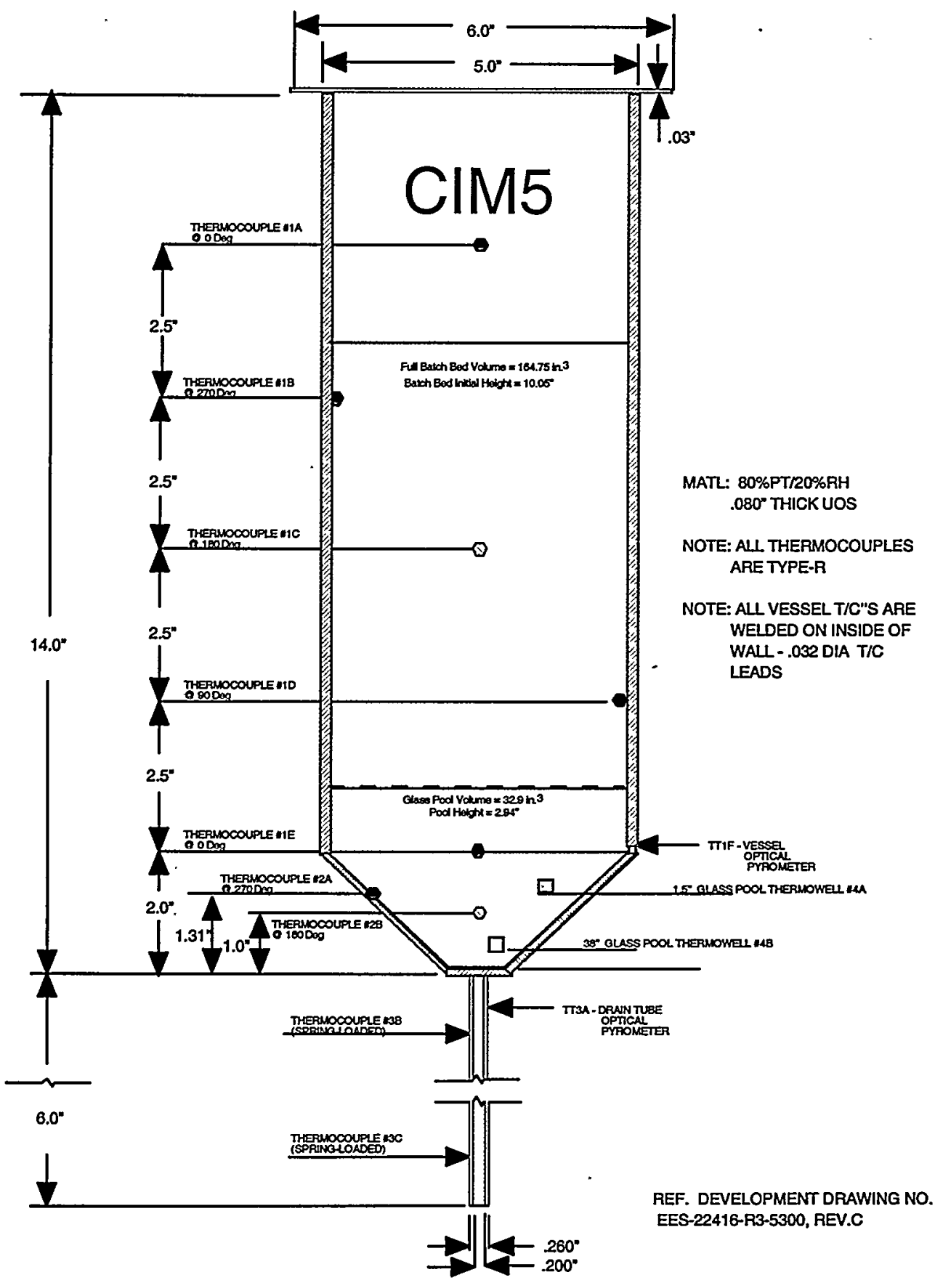




\section{DISTRIBUTION:}

L. M. Papouchado, 773-A

E. W. Holtzscheiter, 773-A

L. F. Landon, 704-1T

M. A. Baich, 704-1T

D. C. Witt, 704-1T

T. M. Jones, 704-1T

D. H. Miller, 704-1T

M. E. Stone, 704-1T

T. K. Snyder, 704-T

D. K. Peeler, 773-43A

C. B. Miller, 773-A

Am/Cm File, 704-1T

STI, 703-43A (4)

ITS-99-0100 File 